\title{
Tissue-specific estrogenic and non-estrogenic effects of a xenoestrogen, nonylphenol
}

\author{
H Watanabe, A Suzuki, M Goto, D B Lubahn'1, H Handa² and T Iguchi \\ Center for Integrative Bioscience, Okazaki National Research Institutes, 5-1 Higashiyama, Myodaiji, Okazaki 444-8585, Japan and Core Research for \\ Evolution Science and Technology (CREST), Japan Science and Technology Corporation, Kawaguchi 332-0012, Japan \\ ${ }^{1}$ Department of Molecular Biology, University of Missouri, Columbia, Missouri 65211, USA \\ 2Frontier Collaborative Research Center, Tokyo Institute of Technology, 4259 Nagatsuta-cho, Yokohama, Kanagawa 226-8503, Japan
}

(Requests for offprints should be addressed to T Iguchi; Email: taisen@nibb.ac.jp)

\begin{abstract}
Alkylphenols perturb the endocrine system and are considered to have weak estrogenic activities. Although it is known that nonylphenol can bind weakly to the estrogen receptor, it is unclear whether all reported effects of nonylphenol are attributable to its estrogen receptor-binding activity. In order to examine whether alkylphenols have similar effects to the natural hormone, estradiol, we used a mouse model to examine the effects of nonylphenol on gene expression and compared it with estradiol. DNA microarray analysis revealed that, in the uterus, most of the genes activated by this alkylphenol at a high dose $(50 \mathrm{mg} / \mathrm{kg})$ were also activated by estradiol. At lower doses, nonylphenol $(0.5 \mathrm{mg} / \mathrm{kg}$ and $5 \mathrm{mg} / \mathrm{kg})$ had little effect on the genes that were activated by estradiol. Thus, we concluded that the effects of nonylphenol at a high dose $(50 \mathrm{mg} / \mathrm{kg})$ were very similar to estradiol in uterine tissue. Moreover, since evaluation of estrogenic activity by gene expression levels was comparable with the uterotrophic assay, it indicated that analysis of gene expression profiles can predict the estrogenic activities of chemicals. In contrast to the similar effects of nonylphenol and estradiol observed in the uterus, in the liver, gene expression was more markedly affected by nonylphenol than by estradiol. This indicated that, in the liver, nonylphenol could activate another set of genes that are distinct from estrogen-responsive genes. These results indicated that nonylphenol has very similar effects to estradiol on gene expression in uterine but not in liver tissue, indicating that tissue-specific effects should be considered in order to elucidate the distinct effects of alkylphenols.
\end{abstract}

Journal of Molecular Endocrinology (2004) 33, 243-252

\section{Introduction}

There has recently been considerable concern about the potential endocrine-disrupting effects of chemicals released into the environment. Those chemicals that have estrogenic activity are termed xenoestrogens or endocrine disruptors. They are thought to mimic or disturb the function of estrogen and many are known to possess estrogen receptor-binding activity (Danzo 1997). Among the xenoestrogens, alkylphenols have been recognized to bind to estrogen receptors and exert weak estrogenic activities in vivo and in vitro (Mueller \& Kim 1978, White et al. 1994). The estrogenic activity of alkylphenol compounds has been reported not only in laboratory-based studies (Soto et al. 1991, Shelby et al. 1996), but also in wildlife (Tyler et al. 1998), especially fish (Flouriot et al. 1995, Sumpter \& Jobling 1995).

Since the original discovery of the estrogenic activity of alkylphenols, many further studies have reported diverse adverse effects of these compounds. For example, in animals exposed to nonylphenol, the weight of the epididymis was decreased (Hossaini et al. 2001), sperm function was affected (Chapin et al. 1999, Adeoya-Osiguwa et al. 2003) and deleterious effects on mammary gland and uterine function were observed (Odum et al. 1999, Danzo et al. 2002).

Despite these studies, the precise mechanisms underlying the adverse effects of endocrinedisrupting chemicals are poorly understood. 
Although it is well established that nonylphenol binds the estrogen receptor, it is not certain that all effects of nonylphenol can be explained by this binding activity. To determine whether the diverse effects of nonylphenol are wholly attributable to its estrogen receptor-binding activity, it is essential to compare nonylphenol and estradiol with respect to gene activation. Thus, we here analyzed gene expression patterns caused by nonylphenol and estradiol using microarray technology.

\section{Materials and methods}

\section{Animals}

Animals were housed under a $12 \mathrm{~h}$ light: $12 \mathrm{~h}$ darkness cycle. ER $\alpha$ knockout ( $\alpha \mathrm{ERKO}$ ) mice (Lubahn et al. 1993) and their wild-type counterparts (C57/BL6/J background) were ovariectomized at 8 weeks of age. After 2 weeks, the ovariectomized mice were injected intraperitoneally with a chemical or sesame oil (Nakarai Tesque, Kyoto, Japan) as a vehicle control and whole uteri $(n=4)$ were collected $6 \mathrm{~h}$ after dosage. Doses of estrogens used were: $50 \mu \mathrm{g} / \mathrm{kg}$ body weight (BW); $5 \mu \mathrm{g} / \mathrm{kg} \mathrm{BW;} 0.5 \mu \mathrm{g} / \mathrm{kg} \mathrm{BW}$; and $0.05 \mu \mathrm{g} / \mathrm{kg}$ BW for $17 \beta$-estradiol (Sigma, SigmaAldrich Japan, Tokyo, Japan) and $50 \mathrm{mg} / \mathrm{kg} \mathrm{BW}$; $5 \mathrm{mg} / \mathrm{kg} \mathrm{BW}$; and $0.5 \mathrm{mg} / \mathrm{kg}$ BW for nonylphenol (Nakarai Tesque). For the uterotrophic assay, ovariectomized mice were injected intraperitoneally with estrogen or sesame oil every $24 \mathrm{~h}$ for 7 days and whole uteri $(n=5)$ were collected and weighed $6 \mathrm{~h}$ after the last dosage. The tissues were then fixed in formalin, embedded in paraffin, cut into $8 \mu \mathrm{m}$ sections and the number of glands was counted. All animal experiments were approved by the institutional Animal Care Committee.

\section{DNA microarray analysis}

Total uterine RNA was extracted using TRIZOL (Invitrogen, Tokyo, Japan) and purified using an RNeasy mini kit (Qiagen, Tokyo, Japan). Purified RNA was labeled with biotin according to the manufacturer's protocol and hybridized with a mouse genome U74Av2 array (Affymetrix Japan, Tokyo, Japan). After washing, the array was scanned to measure fluorescent intensity that is representative of gene expression.
The fluorescent intensity of each probe was further analyzed by dChip, a model-based expression analysis program (Baccarelli et al. 2002) and expression levels were estimated. For the analysis, a perfect match (PM)-only model (Baccarelli et al. 2002) was used. The estimated values (gene expression levels) were transferred to the GeneSpring software program (Silicon Genetics, Redwood City, CA, USA) and analyzed. To deduce credible gene expression levels from DNA microarray analysis, we independently repeated each experiment at least twice, with averaged values being used for the analysis.

For the clustering analysis, genes whose expression levels exceeded 1000 were selected and similarities between experiments and genes were measured by standard correlation using the GeneSpring program. After selecting the genes that were activated more than twofold by nonylphenol, k-means analysis was performed using the GeneSpring program beginning from five random starting clusters.

\section{Quantitative real-time PCR}

Total RNA was purified as described above. cDNA was synthesized from purified total RNA by Superscript II RT(-) (Invitrogen) with random primers at $42{ }^{\circ} \mathrm{C}$ for $60 \mathrm{~min}$. PGR reactions were performed in the PE Prism 5700 sequence detector (PE Biosystems, Tokyo, Japan) using SYBR-Green PCR core reagents (PE Biosystems) in the presence of appropriate primers according to the manufacturer's instructions. Each PCR amplification was performed in triplicate under the following conditions: $2 \mathrm{~min}$ at $50{ }^{\circ} \mathrm{C}$ and $10 \mathrm{~min}$ at $95^{\circ} \mathrm{C}$, followed by a total of 40 two temperature cycles $\left(15 \mathrm{~s}\right.$ at $95^{\circ} \mathrm{C}$ and $1 \mathrm{~min}$ at $\left.60{ }^{\circ} \mathrm{C}\right)$.

Gene expression levels were normalized to the expression levels of L8 mRNA (U67771) and gel electrophoresis and melting curve analyses were performed to confirm correct amplicon size and the absence of non-specific bands.

The primers were chosen to amplify short PCR products of less than 100 base pairs and their sequences are as follows. X79003 (integrin a5), GCGGAAGAGGGAGTGGAAT, CGGAGGGG TCAGCACCTT; L32752 (Ran GTPase), TTG GAGTTGGTTGCAATGC, ACTGTGCTGCAA AAGCTGG; L40406 (hsp-E7I), GGAACGACG GAAAGTGTTGG， CCTGTGAAGTCGGGTG 
Table 1 Correlation coefficients between repetitive experiments for the same condition

\begin{tabular}{l|llll} 
Oil & Exp 1 & Exp 2 & Exp 3 & Exp 4 \\
\hline Exp 1 & \multirow{2}{*}{1.00} & 0.94 & 0.97 & 0.93 \\
Exp 2 & & 1.00 & 0.92 & 0.94 \\
Exp 3 & & & 1.00 & 0.90 \\
Exp 4 & & & & 1.00
\end{tabular}

\begin{tabular}{l|lll} 
Exp 4 & & & \\
E2 $(5 \mu \mathrm{g})$ & $\operatorname{Exp~1}$ & $\operatorname{Exp} 2$ & $\operatorname{Exp~3}$ \\
\hline Exp 1 & 1.00 & 0.91 & 0.92 \\
Exp 2 & & 1.00 & 0.96 \\
Exp 3 & & & 1.00
\end{tabular}

\begin{tabular}{lll} 
NP $(0.05 \mathrm{mg})$ & NP $(0.5 \mathrm{mg})$ & $\mathrm{NP}(50 \mathrm{mg})$ \\
\hline 0.96 & 0.95 & 0.93 \\
E2 $(0.05 \mu \mathrm{g})$ & E2 $(0.5 \mu \mathrm{g})$ & E2 $(50 \mu \mathrm{g})$ \\
\hline 0.96 & 0.96 & 0.96
\end{tabular}

Control experiments (oil) were repeated four times and correlation coefficients between each experiment are indicated in a matrix. Estradiol treatments $(5 \mu \mathrm{g} / \mathrm{kg} \mathrm{BW})$ were independently repeated three times and the correlation coefficient between each experiment is indicated as a matrix. Other experiments were repeated twice for each condition and the correlation coefficients between two experiments are indicated for the compounds and doses in the non-matrix section. E2, estadiol; NP, nonylphenol. The doses (per kg BW) are indicated in parentheses.

CAAT; U90446 (RNAse L inhibitor), GAGGAAC CAAGGACAACGTAAAAC, TGCTATTTCGC TGCACTCACTG; Z18272 (collagen $\alpha 2$ type VI), CGATTGGCTGTGAGAAGCG， CTCGGACA CGAGGTCAGAGAA; AF000236 (orphan chemokine receptor), AGGACGGGATGTCTCTCG ATT, GTTGATGAGCTCTGTTGATTGACG; U67771 (ribosome L8) ACAGAGCGGTTGTTGG TGTTG, GAGGAGTTGCTGTTTGGGTTGT.

\section{Results}

\section{Reproducibility of the DNA microarray analysis}

In order to compare the changes in gene expression caused by nonylphenol and estradiol, we administered either agent to mice and examined gene expression profiles by DNA microarray analysis. The reproducibility of the experiments was evaluated by calculating correlation coefficients between experiments under the same conditions as shown in Table 1. As all combinations of experiments for the same condition had a correlation coefficient of at least $0 \cdot 9$, our DNA microarray data was highly reproducible.

\section{Dose-dependent gene activation by estradiol and nonylphenol}

In response to increasing amounts of nonylphenol or estradiol, gene expression levels changed significantly (Fig. 1). The $\mathrm{r}^{2}$ value calculated between treated and control gene expression levels changed dose dependently with increasing doses of estradiol (Table 2), but that of nonylphenol was lower at 0.5 than at $5 \mathrm{mg} / \mathrm{kg}$. In agreement with these $r^{2}$ values, gene expression was modulated more significantly at $0.5 \mathrm{mg} / \mathrm{kg}$ nonylphenol than at $5 \mathrm{mg} / \mathrm{kg}$ nonylphenol. As the number of genes activated by nonylphenol at the highest dose (50 mg/kg) (307 genes) was greater than for estradiol (238 genes; Table 2), we examined its influence on the gene expression pattern in more detail.

\section{Evaluation of relative estrogenic activity of nonylphenol from gene expression patterns}

To examine whether the genes activated by nonylphenol were similar to those activated by estradiol, we selected 307 genes that were induced more than twofold at the highest dose of nonylphenol (Table 2) and performed hierarchal clustering analysis. As shown in the dendrogram (Fig. 2), the expression pattern caused by the highest dose of nonylphenol was equivalent to that observed between 5 and $0.5 \mu \mathrm{g} / \mathrm{kg}$ estradiol. Although one cluster of genes had a dosedependent gene activation pattern (Fig. 2), the other cluster showed no prominent dose-dependent gene activation.

\section{Genes activated by nonylphenol are also activated by estradiol}

As clustering analysis indicated that the gene activation patterns of nonylphenol and estradiol were similar, we further examined whether the genes activated by nonylphenol were the same as those activated by estradiol. We applied the k-means method to the selected 307 genes to determine if they were also activated by estradiol. If some genes were activated only by nonylphenol, the presence of a cluster that was activated by 

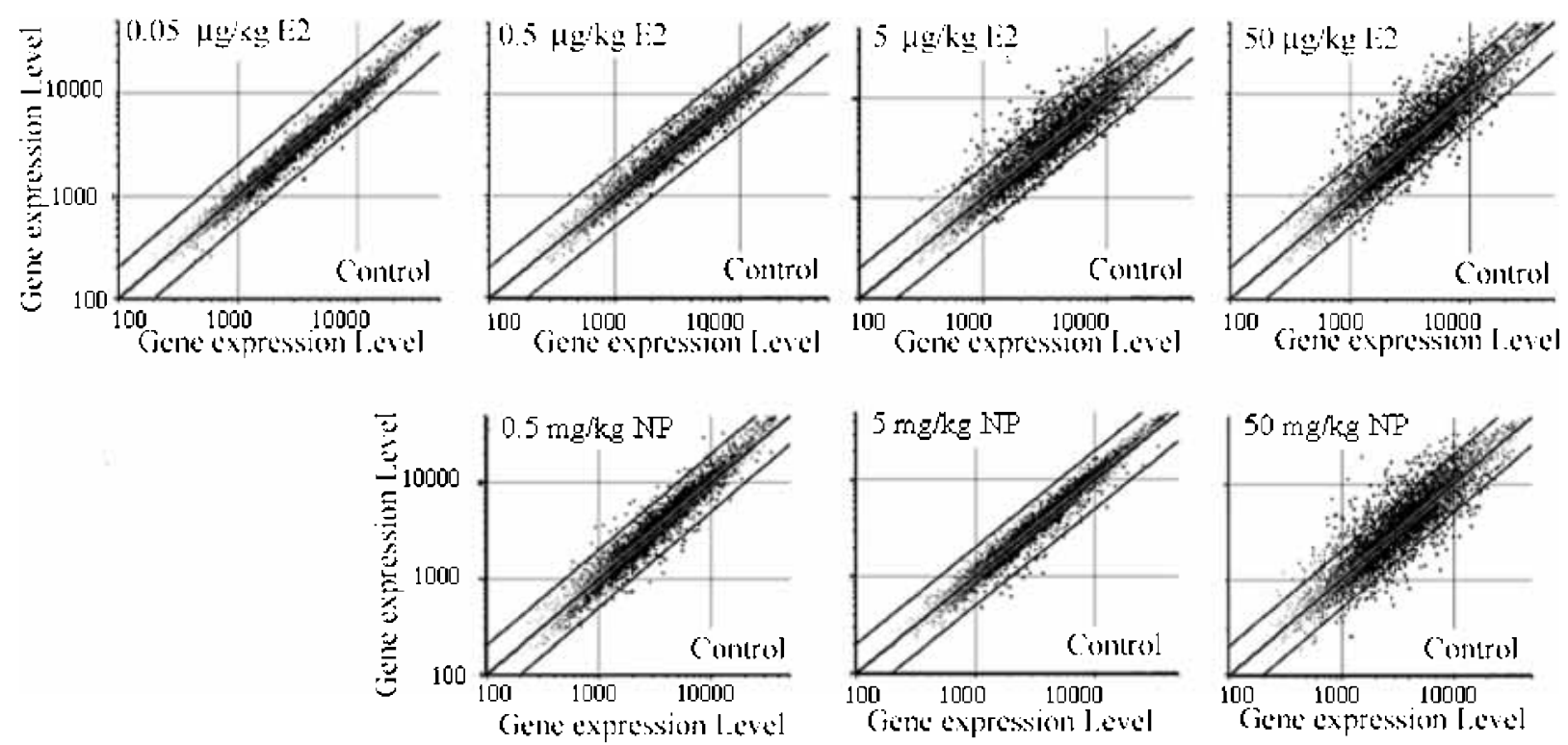

Figure 1 Scatter plot of gene expression levels changed by nonylphenol or estradiol in the uterus.

Ovariectomized mice were given either nonylphenol or estradiol and gene expression levels were evaluated by DNA microarray analysis after $6 \mathrm{~h}$. The gene expression levels (see Materials and methods) of treated and control animals were compared by scatter plot. The $X$ axis indicates gene expression levels in control (oil-treated) and the $\mathrm{Y}$ axis indicates the gene expression levels in treated mice. Each treatment is indicated in the respective panel with its dose. NP, nonylphenol; E2, estradiol.

Table 2 Number of genes whose expression levels were activated or repressed more than twofold

\begin{tabular}{|c|c|c|c|c|c|c|c|}
\hline & \multicolumn{4}{|c|}{ Estradiol ( $\mu \mathrm{g} / \mathrm{kg})$} & \multicolumn{3}{|c|}{ Nonylphenol (mg/kg) } \\
\hline & $\overline{0.05}$ & 0.5 & 5 & 50 & 0.5 & 5 & 50 \\
\hline $\begin{array}{l}F C>2 \\
F C<0.5 \\
r^{2}\end{array}$ & $\begin{array}{l}0 \\
5 \\
0.99\end{array}$ & $\begin{array}{l}14 \\
2 \\
0.98\end{array}$ & $\begin{array}{r}218 \\
28 \\
0.95\end{array}$ & $\begin{array}{r}238 \\
61 \\
0.94\end{array}$ & $\begin{array}{l}38 \\
29 \\
0.97\end{array}$ & $\begin{array}{c}1 \\
21 \\
0.98\end{array}$ & $\begin{array}{l}307 \\
162 \\
0.91\end{array}$ \\
\hline
\end{tabular}

Number of genes that were activated more than twofold $(F C>2)$ or repressed more than twofold $(F C<0.5)$ are indicated. Equations of regression lines were calculated from scatter plots in Fig. 1 (treated vs control) and $r^{2}$ values were calculated.

nonylphenol, but not by estradiol, could be expected. However, even when we increased the number of clusters, we could not identify any cluster that clearly indicated the presence of genes activated by nonylphenol but not estradiol. Figure 3 shows the result of clustering using three clusters. Among the three gene clusters, two clusters (Fig. $3 \mathrm{~B}-\mathrm{C}$ ) showed a rather similar pattern. They were activated by estradiol in a dose-dependent manner and activated by nonylphenol only at the highest dose but exhibited no clear dose-dependent pattern in response to nonylphenol. One cluster (Fig. 3A) showed an atypical pattern compared with the other clusters, with those genes being activated more markedly at the highest dose of nonylphenol. Importantly, dose-dependent gene activation by estradiol correlated with uterotrophic effects, as shown in Fig. 3D. These results indicated that estrogenic activities of nonylphenol can also be estimated by gene expression profiling. The total number of genes activated more than twofold by nonylphenol (307 genes) was greater than that for estradiol (238 genes). These genes were mainly contained within one cluster (Fig. 3A and data not shown), but they were not nonylphenol specific because they were also activated by estradiol, albeit with weaker effects. As shown in Fig. 3, almost all genes that were activated by the high dose of 


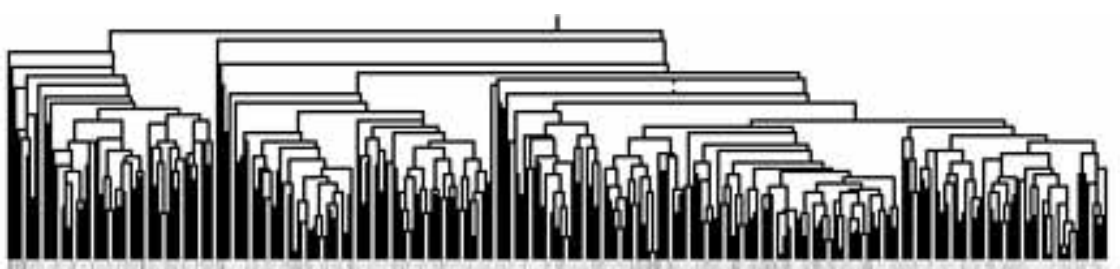

\section{oil E2(0.00005) \\ $\mathrm{NP}(0.5)$ \\ NP(5) \\ $\mathrm{E} 2(0.0005)$ \\ NP(50) \\ E2(0.005) \\ E2(0.05)}

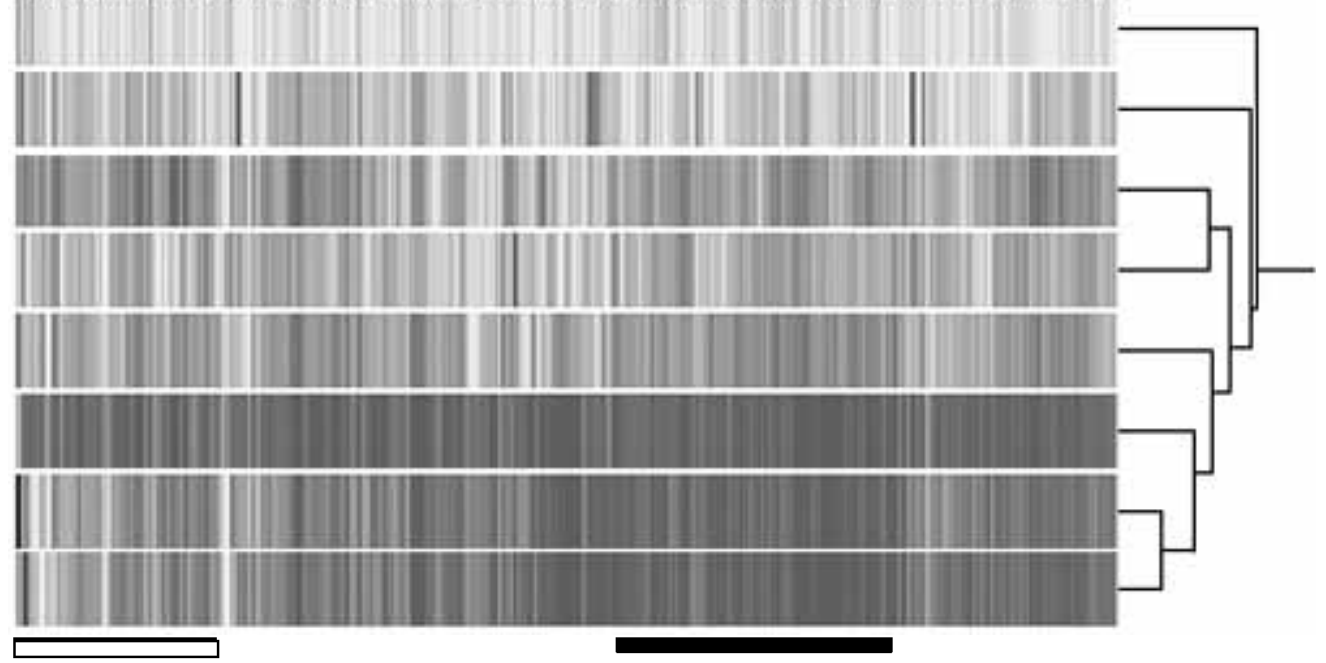

Figure 2 Clustering analysis of nonylphenol-induced genes. For the analysis, 307 genes activated by nonylphenol more than twofold at a dose of $50 \mathrm{mg} / \mathrm{kg}$ were selected and expression values under each condition were calculated. The calculated expression levels were then clustered. Treatments are indicated for the respective lanes. A cluster of genes that is representative of the dendrogram is indicated by a solid bar on the right. A cluster of genes that does not correlate with the dose is indicated by an open bar. Numbers indicate the dose administered $(\mathrm{mg} / \mathrm{kg})$. NP, nonylphenol; E2, estradiol.

nonylphenol or by estradiol were not activated in ERKO mice. Thus, those genes that were upregulated by both nonylphenol and estradiol were activated by the estrogen receptor, either directly or indirectly. These similar gene activation patterns were confirmed by quantitative real-time PCR (Fig. 4).

\section{Gene activation profile of nonylphenol in liver}

As our results in the uterus suggested that nonylphenol and estradiol have similar effects on gene expression, at least at some doses, we examined whether the effects of these chemicals were also similar in another tissue, liver, again using DNA microarrays. As $5 \mu \mathrm{g} / \mathrm{kg}$ estradiol and $50 \mathrm{mg} / \mathrm{kg}$ nonylphenol could activate gene expression to similar extents in the uterus (Fig. 5A and C), we administered these doses and examined resultant changes in liver gene expression. This indicated that in liver, nonylphenol activated more genes than estradiol (Fig. 5B and $\mathrm{C}$ ). Calculation of fold change of each gene by estradiol or nonylphenol indicated that in liver, gene activation induced by nonylphenol was different from that induced by estradiol (Fig. 5C). The list of the genes that were activated more markedly by nonylphenol than by estradiol is shown in Table 3. Overall, our results indicated that nonylphenol and estradiol similarly affect uterine gene expression but have different effects on liver gene expression.

\section{Discussion}

In this study, we examined whether nonylphenol has effects on gene expression that are distinct from estrogenic effects, by comparing its effects on gene expression with those of estradiol. Several doses were used since comparison of changes in gene expression at one dose cannot be used to validly estimate the activities of chemicals (Watanabe et al. 2003). In summary, we demonstrated that (1) the estrogenic activity of nonylphenol could be 

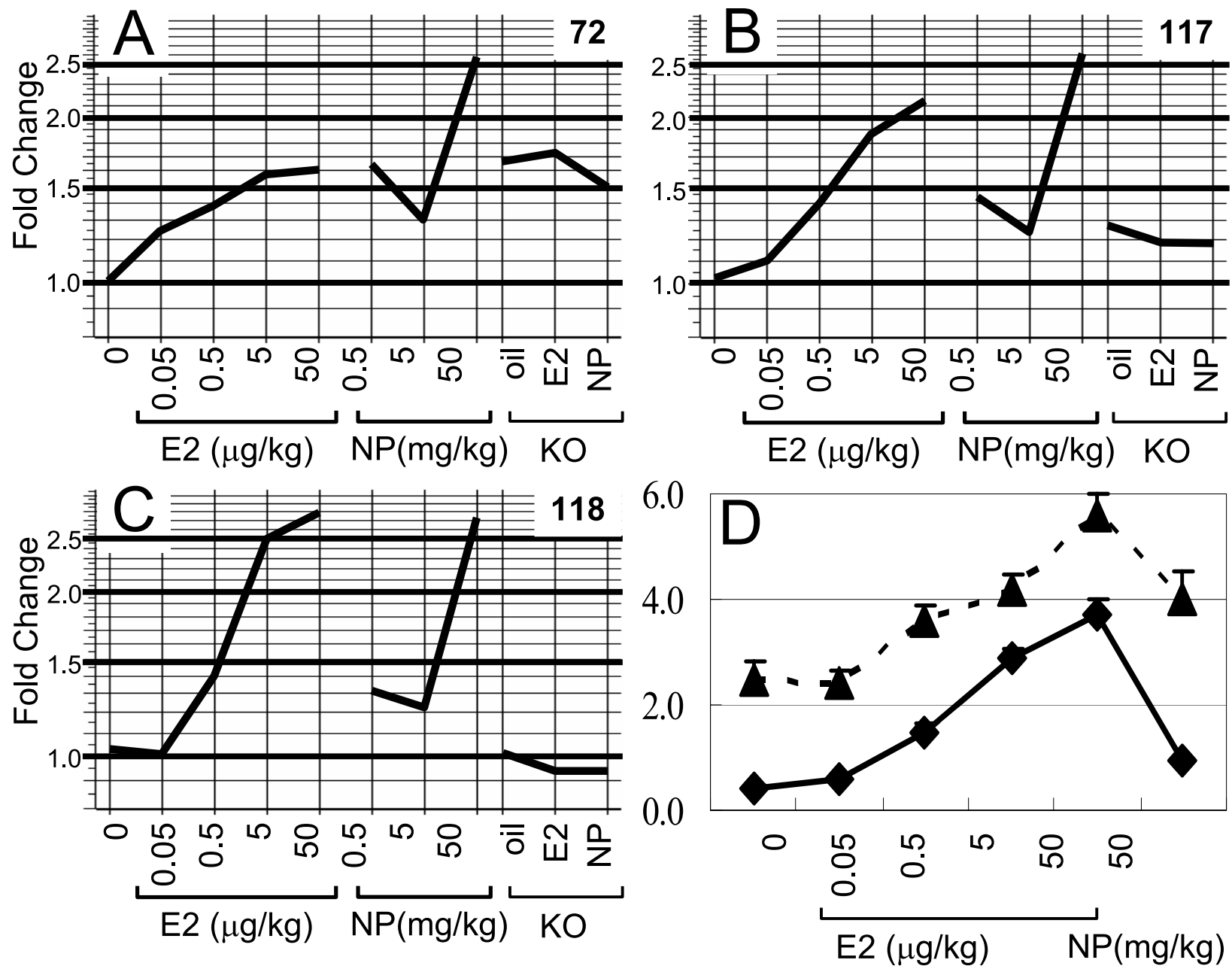

Figure $3 \mathrm{k}$-means analysis of nonylphenol-activated genes. To examine dose-dependent gene activation patterns, genes that were activated by nonylphenol more than twofold were selected and clustered by k-means (number of class was three). Average values of fold changes in each cluster are indicated in each panel (A-C). Numbers of the clustered genes are indicated at the top right of each panel. KO indicates the gene activation profile of ERKO mice. Oil, control; E2, $5 \mu \mathrm{g} / \mathrm{kg}$ estradiol; NP, $50 \mathrm{mg} / \mathrm{kg}$ nonylphenol. The dose ranges were 0.05, 0.5, 5 and $50 \mu \mathrm{g} / \mathrm{kg}$ for estradiol and $0.5,5$ and $50 \mathrm{mg} / \mathrm{kg}$ for nonylphenol, which are indicated on the $\mathrm{X}$ axis. (D) The results of the uterotrophic assay (mg of uterine weight $/ \mathrm{g} \mathrm{BW}$ ) are indicated by the solid line and the numbers of glands under the same conditions are indicated by the broken line.

estimated from gene expression profiling, and this was comparable with results obtained in the uterotrophic assay; (2) almost all genes activated by estradiol in the uterus were also activated by nonylphenol at a high dose; and (3) nonylphenol and estradiol have similar effects on gene expression in the uterus, but not in the liver.

Our clustering analysis indicated that the relative activity of nonylphenol estimated from gene expression levels was between 0.001 and 0.0001 (relative to an activity of estradiol equal to 100)
(Fig. 2), which was consistent with the value of 0.00036 estimated in a previous study (Coldham et al. 1997). This value was also consistent with previous estimations using the uterotrophic assay and other studies using other systems such as E-screen (Soto et al. 1995, Kwack et al. 2002), a yeast reporter system (Coldham et al. 1997, Andersen et al. 1999) and a ligand-binding assay (Coldham et al. 1997, Andersen et al. 1999).

Our analysis also found that lower doses of nonylphenol did not exhibit estrogenic effects on 


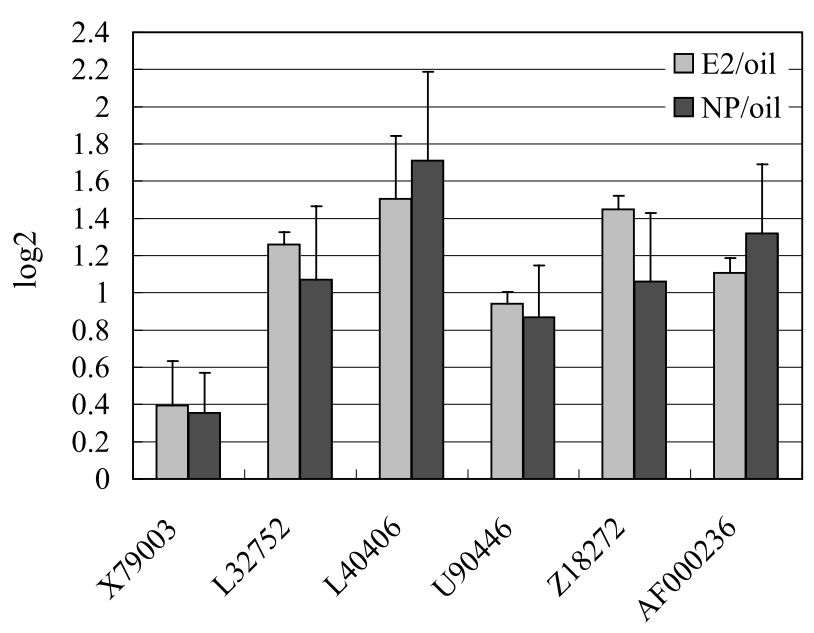

Figure 4 Quantification of mRNA by real-time PCR. Selected gene expression levels, as identified by DNA microarray analysis, were examined by real-time PCR. Nonylphenol (NP) or estradiol (E2) treatments were repeated three times and evaluations of gene expression changes were performed independently. Average values of the fold changes and their error are indicated. GeneBank accession numbers of the selected genes are indicated. X79003, integrin $\alpha 5$; L32752, GTPase (Ran); L40406, hsp-E7I; U90446, RNAse L inhibitor; Z18272, collagen $\alpha 2$ chain type VI; AF000236, orphan chemokine receptor.

gene expression. Although genes were activated in a dose-dependent manner by estradiol in three orders of magnitude $(0 \cdot 5-50 \mu \mathrm{g} / \mathrm{kg})$, they were activated by only one dose $(50 \mathrm{mg} / \mathrm{kg})$ of nonylphenol and there was no clear dose-response by nonylphenol. This is clearly illustrated in Fig. 2 where a mid-range dose of nonylphenol $(5 \mathrm{mg} / \mathrm{kg})$ is not positioned between $5 \mu \mathrm{g} / \mathrm{kg}$ and $0.5 \mu \mathrm{g} / \mathrm{kg}$ estradiol. Although k-means analysis indicated subsets of genes that were activated at $0.5 \mathrm{mg} / \mathrm{kg}$ nonylphenol, this activation pattern was distinct from the effects of estradiol, as indicated in Fig. 3. This indicated that the effect of nonylphenol at lower doses is not due to the general estrogenic activity of the chemical and that nonylphenol has estrogenic effects only at the highest dose.

In addition to the above findings, another important finding in this study was that the difference in gene activation profiles between nonylphenol and estradiol was much greater in the liver than in the uterus. Nonylphenol-specific changes in gene expression were not prominent in the uterus, whereas in the liver the number of nonylphenol-activated genes was very different from that of estradiol, indicating that their effects on gene expression are tissue specific. This indicated that evaluations of chemical activities which rely on one cell line may be insufficient for validation, and the use of tissues may be critical in order to fully understand the chemical effects.

With regard to the genes that were activated by nonylphenol but not by estradiol in the liver, many genes involved in lipid or fatty acid metabolism were detected in addition to cytochrome $\mathrm{P} 450$ genes. These included apolipoprotein A-IV, peroxiredoxin, granulin and lecithin cholesterol acyltransferase, which are involved in lipid metabolism, and acetyl-CoA acyltransferase, which is involved in the metabolism of fatty acids. In rodents, it has been
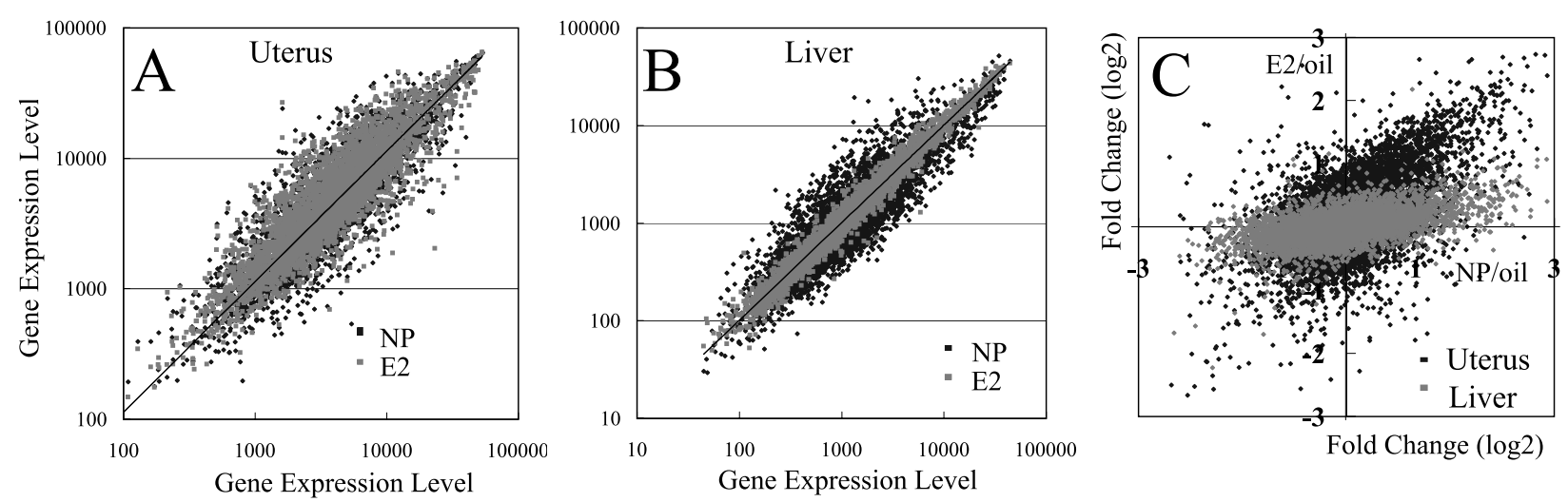

Figure 5 Scatter plots and fold changes of gene expression levels in the liver and uterus. Gene expression levels in nonylphenol (NP)- or estradiol (E2)-treated uteri (Y axis) were plotted against control gene expression levels (X axis) (A) and those in the liver were also plotted (B). (C) Fold changes (ratio of treated gene expression level to control gene expression level) were calculated and plotted on a log scale (log2). 
Table 3 List of genes specifically activated by nonylphenol but not by estradiol in the liver

\section{log2}

\begin{tabular}{|c|c|c|c|}
\hline \multirow[b]{2}{*}{ GeneBank number } & NP/oil & E2/oil & Title (annotations, June 2003) \\
\hline & 3.86 & 1.37 & Cutochrome P450 familv 2 subfamily d nolvnentide 10 \\
\hline AB025217 & 3.27 & 0.81 & Calcium-binding protein P22 \\
\hline M76131 & 3.07 & 0.89 & Eukaryotic translation elongation factor 2 \\
\hline AF093853 & $2 \cdot 82$ & 1.05 & Peroxiredoxin 6 \\
\hline AB003304 & 2.69 & 1.04 & Proteasome (prosome, macropain) subunit, $\beta$ type 5 \\
\hline D87898 & $2 \cdot 68$ & 0.94 & ADP-ribosylation factor 1 \\
\hline V00714 & $2 \cdot 60$ & 0.26 & Hemoglobin $\alpha$, adult chain 1 \\
\hline AB020203 & 2.59 & $0 \cdot 16$ & Adenylate kinase $3 \alpha$-like \\
\hline U03715 & $2 \cdot 55$ & 0.58 & Procollagen, type XVIII, $\alpha 1$ \\
\hline AW045202 & 2.47 & 0.63 & Protein disulfide isomerase-related protein \\
\hline L39879 & 2.44 & 0.78 & Ferritin light chain 1 \\
\hline D17571 & $2 \cdot 40$ & 0.73 & P450 (cytochrome) oxidoreductase \\
\hline M27134 & $2 \cdot 38$ & 0.26 & Histocompatibility 2, Q region locus 10 \\
\hline Al839702 & 2.35 & 0.51 & Copper chaperone for superoxide dismutase \\
\hline Z97207 & $2 \cdot 34$ & 0.69 & Butyrate-induced transcript 1 \\
\hline AF115480 & $2 \cdot 28$ & 0.67 & cAMP-regulated guanine nucleotide exchange factor II \\
\hline X57024 & $2 \cdot 27$ & 0.55 & Glutamate dehydrogenase \\
\hline AV003378 & $2 \cdot 26$ & 0.05 & Hemoglobin $\alpha$, adult chain 1 \\
\hline M64248 & $2 \cdot 24$ & 0.65 & Apolipoprotein A-IV \\
\hline AW012807 & $2 \cdot 23$ & 0.87 & GrpE-like 1, mitochondrial \\
\hline Al530403 & $2 \cdot 21$ & 0.43 & Acetyl-coenzyme A acyltransferase 1 \\
\hline L47335 & $2 \cdot 20$ & 0.43 & Branched chain ketoacid dehydrogenase E1, $\alpha$ polypeptide \\
\hline U65403 & $2 \cdot 20$ & 0.92 & Seum amyloid $A 4$ \\
\hline L12140 & $2 \cdot 20$ & 0.44 & Amino-terminal enhancer of split \\
\hline U35741 & $2 \cdot 20$ & 0.42 & Thiosulfate sulfuotransferase, mitochondrial \\
\hline Al842889 & $2 \cdot 17$ & $0 \cdot 21$ & ATPase, $\mathrm{H}^{+}$transporting V0 subunit B \\
\hline AF030065 & $2 \cdot 16$ & 0.43 & Hepsin \\
\hline J05154 & $2 \cdot 16$ & 0.46 & Lecithin cholesterol acyltransferase \\
\hline AW045202 & $2 \cdot 15$ & 0.43 & Protein disulfide isomerase-related protein \\
\hline $\mathrm{X} 17069$ & $2 \cdot 15$ & 0.44 & FK506 binding protein 4 \\
\hline AA795613 & $2 \cdot 15$ & 0.50 & Transcription elongation factor $B(S I I)$, polypeptide $2(18 \mathrm{kDa}$, elongin $\mathrm{B})$ \\
\hline X76850 & $2 \cdot 13$ & 0.92 & MAP kinase-activated protein kinase 2 \\
\hline D87896 & $2 \cdot 12$ & 0.56 & Glutathione peroxidase 4 \\
\hline X66091 & $2 \cdot 12$ & 0.91 & Splicing factor, arginine/serine-rich 1 (ASF/SF2) \\
\hline AF091390 & 2.09 & 0.43 & FXYD domain-containing ion transport regulator 1 \\
\hline $\mathrm{J} 00413$ & 2.09 & 0.71 & Hemoglobin, $\beta$ adult major chain \\
\hline Al853523 & 2.09 & 1.06 & Ubiquinol-cytochrome c reductase subunit \\
\hline AW045751 & $2 \cdot 07$ & -0.36 & Quiescin Q6 \\
\hline AW122731 & 2.05 & 0.20 & Diaphorase 1 (NADH) \\
\hline X05021 & 2.05 & 0.58 & Ribosomal protein L27a \\
\hline AW123952 & 2.05 & $0 \cdot 70$ & ATPase, $\mathrm{Na}^{+} / \mathrm{K}^{+}$transporting, $\alpha 1$ polypeptide \\
\hline D16333 & 2.05 & $0 \cdot 19$ & Coproporphyrinogen oxidase \\
\hline J05185 & 2.04 & 0.64 & Prolyl 4-hydroxylase, $\beta$ polypeptide \\
\hline AW123556 & 2.04 & 0.42 & Quiescin Q6 \\
\hline AW120711 & 2.04 & 0.32 & DNAJ (Hsp40) homolog, subfamily B, member 9 \\
\hline X04435 & 2.03 & -0.08 & Nuclear receptor subfamily 3 , group C, member 1 \\
\hline U29402 & 2.03 & 0.46 & Ribosomal protein, large, $\mathrm{P} 1$ \\
\hline M77196 & 2.02 & -0.08 & CEA-related cell adhesion molecule 1 \\
\hline L00919 & 2.02 & 0.32 & Erythrocyte protein band 4.1 \\
\hline AA838868 & $2 \cdot 01$ & $0 \cdot 10$ & Latent transforming growth factor $\beta$ binding protein 4 \\
\hline L31777 & $2 \cdot 01$ & 0.45 & Triosephosphate isomerase \\
\hline D16195 & $2 \cdot 00$ & 0.36 & Granulin \\
\hline
\end{tabular}

The genes with GeneBank accession numbers that were activated more than fourfold by nonylphenol are indicated with fold changes. Fold changes (log2) calculated from the ratio of gene expression levels of nonylphenol (NP) to those of the control (oil) are indicated in the second column. Fold changes (log2) calculated from the ratio of gene expression levels of estradiol (E2) to those of the control (oil) are indicated in the third column. 
reported that estrogen does not affect the expression of lecithin cholesterol acyltransferase (Staels et al. 1992) and that it downregulates the expression of apolipoprotein A-IV (Staels et al. 1990) in the liver - observations with which our results are consistent. Thus activation of these genes in the liver by nonylphenol may not be an estrogenic affect of nonylphenol.

In rodents, peroxisome proliferators are known to affect the expression of genes involved in lipid metabolism. Although peroxisome proliferatoractivated receptors (PPARs) are candidate nonylphenol-responsive transcription factors, a genome-wide gene expression pattern of PPAR $\alpha$ agonists did not overlap with our data, even though the same system was used for the analysis (Yamazaki et al. 2002).

In the liver, steroid and xenobiotic receptor (SXR)/pregnenolone X receptor (Blumberg et al. 1998, Moore et al. 2000) is also known to respond to xenobiotics and to activate a subset of genes (Masuyama et al. 2000, Xie et al. 2000), but it was not clear whether the genes specifically activated by nonylphenol in liver are driven by SXR, since very few SXR-responsive genes (Rosenfeld et al. 2003) are activated by nonylphenol. For example, although CYP3A is one of the prominent genes activated by SXR, here the CYP genes that were activated were CYP2d10, GYP oxidoreductase and ubiquinolcytochrome c reductase. It is possible that in the liver, other transcription factors, such as hepatocyte nuclear factors, may activate genes more strongly than the estrogen receptor. Thus, further study is necessary to clarify the molecular mechanisms of the tissue-specific effects of nonylphenol.

Taken together, our analysis of gene expression not only elucidated the identity of responsive genes and differences in their sensitivities to nonylphenol and estradiol, but also shed light on the tissuespecific effects. These findings will be important for understanding the diverse effects of xenoestrogens.

\section{Acknowledgements}

This study was supported by grants from the Ministry of Education, Culture, Sports, Science and Technology, Ministry of the Environment, New Energy and Industrial Technology Development Organization, CREST and Japan Science and Technology Corporation.

\section{References}

Adeoya-Osiguwa SA, Markoulaki S, Pocock V, Milligan SR \& Fraser LR 200317 beta-Estradiol and environmental estrogens significantly affect mammalian sperm function. Human Reproduction $18100-107$.

Andersen HR, Andersson AM, Arnold SF, Autrup H, Barfoed M, Beresford NA, Bjerregaard P, Christiansen LB, Gissel B, Hummel $\mathrm{R}$ et al. 1999 Comparison of short-term estrogenicity tests for identification of hormone-disrupting chemicals. Environmental Health Perspectives 107 Suppl 1 89-108.

Baccarelli A, Mocarelli P, Patterson DG, Jr., Bonzini M, Pesatori AC, Caporaso N \& Landi MT 2002 Immunologic effects of dioxin: new results from Seveso and comparison with other studies. Environmental Health Perspectives 110 1169-1173.

Blumberg B, Sabbagh W, Jr., Juguilon H, Bolado J, Jr., van Meter CM, Ong ES \& Evans RM 1998 SXR, a novel steroid and xenobiotic-sensing nuclear receptor. Genes and Development 12 3195-3205.

Chapin RE, Delaney J, Wang Y, Lanning L, Davis B, Collins B, Mintz N \& Wolfe G 1999 The effects of 4-nonylphenol in rats: a multigeneration reproduction study. Toxicological Sciences 52 80-91.

Coldham NG, Dave M, Sivapathasundaram S, McDonnell DP, Connor C \& Sauer MJ 1997 Evaluation of a recombinant yeast cell estrogen screening assay. Environmental Health 105 734-742.

Danzo BJ 1997 Environmental xenobiotics may disrupt normal endocrine function by interfering with the binding of physiological ligands to steroid receptors and binding proteins. Environmental Health Perspectives 105 294-301.

Danzo BJ, Shappell HW, Banerjee A \& Hachey DL 2002 Effects of nonylphenol, 1,1-dichloro-2,2-bis(p-chlorophenyl)ethylene (p,p'-DDE), and pentachlorophenol on the adult female guinea pig reproductive tract. Reprod Toxicol 16 29-43.

Flouriot G, Pakdel F, Ducouret B \& Valotaire Y 1995 Influence of xenobiotics on rainbow trout liver estrogen receptor and vitellogenin gene expression. Fournal of Molecular Endocrinology 15 $143-151$

Hossaini A, Dalgaard M, Vinggaard AM, Frandsen H \& Larsen JJ 2001 In utero reproductive study in rats exposed to nonylphenol. Reproductive Toxicology 15 537-543.

Kwack SJ, Kwon O, Kim HS, Kim SS, Kim SH, Sohn KH, Lee RD, Park CH, Jeung EB, An BS et al. 2002 Comparative evaluation of alkylphenolic compounds on estrogenic activity in vitro and in vivo. Fournal of Toxicology and Environmental Health A $\mathbf{6 5}$ 419-431.

Lubahn DB, Moyer JS, Golding TS, Couse JF, Korach KS \& Smithies O 1993 Alteration of reproductive function but not prenatal sexual development after insertional disruption of the mouse estrogen receptor gene. PNAS A 90 11162-11166.

Masuyama H, Hiramatsu Y, Kunitomi M, Kudo T \& MacDonald PN 2000 Endocrine disrupting chemicals, phthalic acid and nonylphenol, activate Pregnane X receptor-mediated transcription. Molecular Endocrinology 14 421-428.

Moore LB, Parks DJ, Jones SA, Bledsoe RK, Consler TG, Stimmel JB, Goodwin B, Liddle C, Blanchard SG, Willson TM et al. 2000 Orphan nuclear receptors constitutive androstane receptor and pregnane $\mathrm{X}$ receptor share xenobiotic and steroid ligands. Fournal of Biolpogical Chemistry 275 15122-15127.

Mueller GC \& Kim UH 1978 Displacement of estradiol from estrogen receptors by simple alkyl phenols. Endocrinology 102 1429-1435.

Odum J, Pyrah IT, Foster JR, Van Miller JP, Joiner RL \& Ashby J 1999 Comparative activities of p-nonylphenol and diethylstilbestrol in noble rat mammary gland and uterotrophic assays. Regulatory Toxicology and Pharmacology 29 184-195.

Rosenfeld JM, Vargas R, Jr., Xie W \& Evans RM 2003 Genetic profiling defines the xenobiotic gene network controlled by the 
nuclear receptor pregnane X receptor. Molecular Endocrinology 17 $1268-1282$.

Shelby MD, Newbold RR, Tully DB, Chae K \& Davis VL 1996 Assessing environmental chemicals for estrogenicity using a combination of in vitro and in vivo assays. Environmental Health Perspectives 104 1296-1300.

Soto AM, Justicia H, Wray JW \& Sonnenschein C 1991 p-Nonyl-phenol: an estrogenic xenobiotic released from "modified" polystyrene. Environmental Health Perspectives 92 $167-173$.

Soto AM, Sonnenschein C, Chung KL, Fernandez MF, Olea N \& Serrano FO 1995 The E-SCREEN assay as a tool to identify estrogens: an update on estrogenic environmental pollutants. Environmental Health Perspectives 103 Suppl 7 113-122.

Staels B, van Tol A, Skretting G \& Auwerx J 1992 Lecithin: cholesterol acyltransferase gene expression is regulated in a tissueselective manner by fibrates. Fournal Lipidid Research 33 727-735.

Staels B, van Tol A, Verhoeven G \& Auwerx J 1990 Apolipoprotein A-IV messenger ribonucleic acid abundance is regulated in a tissue-specific manner. Endocrinology 126 2153-2163.

Sumpter JP \& Jobling S 1995 Vitellogenesis as a biomarker for estrogenic contamination of the aquatic environment. Environmental Health Perspectives 103 Suppl 7 173-178.
Tyler CR, Jobling S \& Sumpter JP 1998 Endocrine disruption in wildlife: a critical review of the evidence. Critical Reviewes in Toxicology 28 319-361.

Watanabe H, Suzuki A, Kobayoshi M, Lubahn DB Handa H \& Iguchi T 2003 Similarity and differences in uterine gene expression patterns caused by treatment with physiological and non-physiological ostrogens. Fournal of Molecular Endocrinology 31 487-497.

White R, Jobling S, Hoare SA, Sumpter JP \& Parker MG 1994 Environmentally persistent alkylphenolic compounds are estrogenic. Endocrinology 135 175-182.

Xie W, Barwick JL, Downes M, Blumberg B, Simon CM, Nelson MC, Neuschwander-Tetri BA, Brunt EM, Guzelian PS \& Evans RM 2000 Humanized xenobiotic response in mice expressing nuclear receptor SXR. Nature 406 435-439.

Yamazaki K, Kuromitsu J \& Tanaka I 2002 Microarray analysis of gene expression changes in mouse liver induced by peroxisome proliferator-activated receptor alpha agonists. Biochemical and Biophysical Research Communications 290 1114-1122.

Received 1 January 2004

Accepted 20 May 2004 